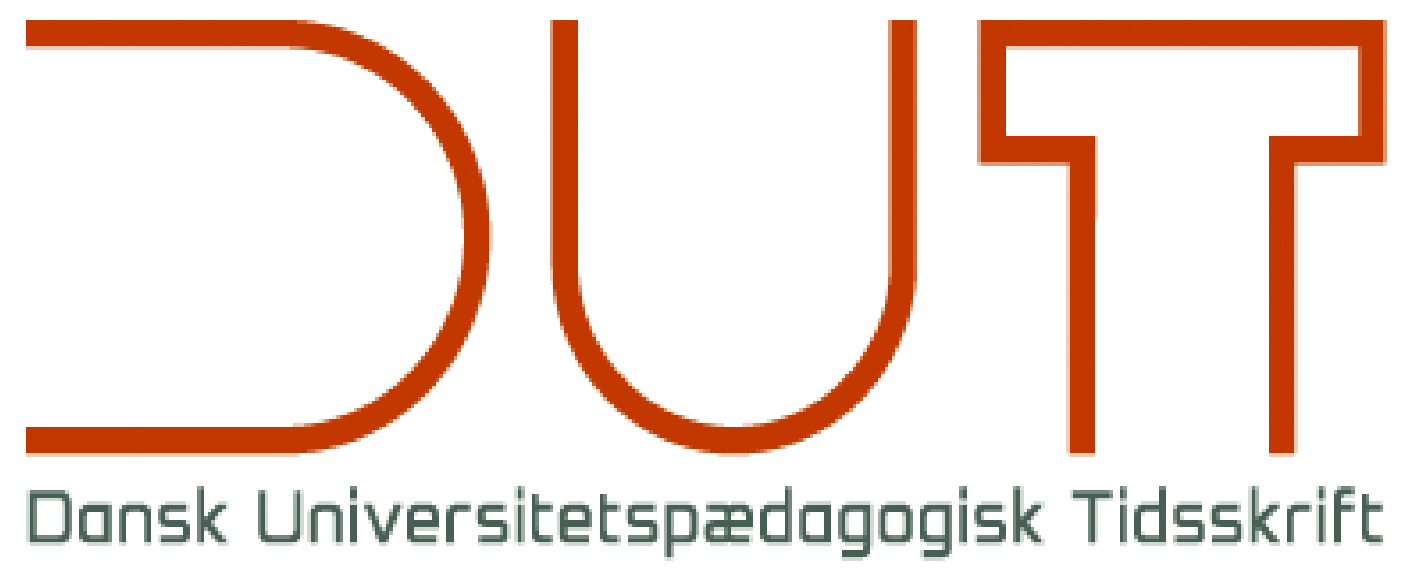

Tema

Fra data til beslutninger

Årgang 14 nr. 26 / 2019

Titel

Kig op! Undervisning uden et blåt skær

Forfattere

Sidetal

Udgivet af

URL

Kim J. Herrmann

$136-138$

Dansk Universitetspædagogisk Netværk, DUN

> http://dun-net.dk/

Betingelser for brug af denne artikel

(C) Copyright
Denne artikel er omfattet af ophavsretsloven, og der må citeres fra den. Følgende betingelser skal dog være opfyldt:

- Citatet skal være i overensstemmelse med "god skik"

- Der må kun citeres „i det omfang, som betinges af formålet“

- Ophavsmanden til teksten skal krediteres, og kilden skal angives ift. ovenstående bibliografiske oplysninger.

DUT og artiklens forfatter 


\title{
Kig op! Undervisning uden et blåt skær
}

\author{
Skrevet af Peter Holdt Christensen \\ Udgivet 2018 på forlaget Samfundslitteratur, 184 sider, ISBN: 978-87-593-3207-8 \\ Anmeldt af Kim J. Herrmann ${ }^{a, 1}$ \\ ${ }^{a}$ Center for Undervisning og Læring, Aarhus Universitet
}

Der findes næppe den underviser på universitetet eller andre videregående uddannelser, som ikke på et eller andet tidspunkt står med det problem, at en del af de studerende - det være sig få eller mange - er fraværende i undervisningen, fordi de læser mails, skriver på Facebook eller tjekker nyheder på nettet. I hvert fald har jeg endnu til gode at møde en underviser, som ikke har en holdning til studerendes brug af bærbare og mobiltelefoner i undervisningslokalet.

Og netop holdninger er der mange af, når det gælder studerendes brug af digitale medier. Til gengæld skorter det ifølge Peter Holdt Christensen på fakta og på aktiv stillingtagen. Derfor har han for nylig udgivet bogen Kig op! Undervisning uden et blåt skoer med det formål at skrive en samlet fremstilling af, hvorfor og hvordan skærmtid udgør et problem for undervisningen. Dels for at muliggøre en saglig diskussion af konsekvenserne af skærmtid i undervisningen, dels for at gøre det muligt for undervisere og uddannelsessteder at tage stilling og handle.

\section{Skærmtid}

Men først tilbage til hvad bogen handler om og ikke handler om. Christensen er interesseret i fænomenet 'skærmtid', hvilket han definerer som tiden brugt på digitale aktiviteter, hvor disse aktiviteter ikke er relevante for den interaktion som foregår i undervisningslokalet. Bogen handler således ikke om digitale aktiviteter uden for det fysiske undervisningsrum, ej heller handler bogen om digitale aktiviteter, som er relevante for undervisningen, som $\mathrm{fx}$ at tage noter på en bærbar.

Og det er en del af pointen. At studerendes brug af digitale medier i undervisningslokalet ikke er et problem per se, men et problem de facto. Dette har dels at gøre med, at mobile apparater og internetadgang er en helt selvfølgelig del af det moderne undervisningslokale, dels at mange mennesker (heriblandt studerende) har udviklet noget, der nærmer sig en afhængighed af nyheder og sociale medier, og denne afhængighed er rykket med ind i undervisningslokalet. Symptomerne er et stigende antal studerende, der har svært ved at koncentrere og fordybe sig, som multitasker uhensigtsmæssigt, og som har svært ved at byde ind i den faglige samtale. Konsekvenserne for den enkelte studerende er et ringere udbytte og lavere karakterer. For den enkelte underviser er konsekvensen, at det bliver sværere at afkode de studerendes signaler og dermed justere tempo og retning i undervisningen, ligesom mange undervisere oplever at blive demotiverede.

\footnotetext{
${ }^{1}$ Kontakt: kh@au.dk
} 


\section{Energifyldte interaktioner}

Men - og det er pointen - problemet er i virkeligheden ikke individuelt. Det er først og fremmest kollektivt. Og for at forstå det, gør Christensen sig umage med at forklare, hvordan vi kan forstå værdien af det fysiske møde mellem underviser og studerende og studerende imellem.

Christensen forklarer med henvisning til sociologen Randall Collins, at når vi som mennesker mødes i en fysisk forsamling, har vi mulighed for at indgå i såkaldte energifyldte interaktioner. 'Energien' opstår, fordi vi er fysisk tilstedeværende, fordi det fysiske rum afgrænser os fra andre, fordi vi er gensidigt opmærksomme, og fordi vi i fællesskab oplever følelser. Er disse fire betingelser opfyldt, har vi mulighed for at opleve energifyldte interaktioner, som er afgørende for vores motivation og engagement. Det samme gælder for mødet i det fysiske undervisningslokale.

Det fysiske møde kan dog lige så vel dræne os for energi i de tilfælde, hvor disse betingelser ikke er opfyldt, og det er netop her, skærmtid udgør en stigende trussel. Den lette adgang til underholdning på nettet gør nemlig, at det i dag er meget nemmere at undslippe det fysiske samvær og flygte ind i det digitale rum, som tilmed er konstrueret med det formål at give os hurtige belønninger, mens fordybelse og engagement i en faglig samtale er meget mere krævende og belønningen meget mere langsom.

Pointen er følgende: Det fysiske møde mellem underviser og studerende rummer - og har altid rummet - et afgørende potentiale i form af energi og motivation for de studerendes læring. Men hvor det før i tiden var meget svært at undslippe den fysiske forsamling, når først vi valgte at tage del i den, så er det i dag meget nemt og uendelig fristende at trække sig tilbage. Og dermed risikerer vi at undergrave forudsætningerne for, at undervisning fylder os med energi og motiverer os til at lære. Konsekvensen er, at det er blevet væsentligt sværere at forløse undervisningens vigtige potentiale for de studerendes læring.

\section{Religionskrig og reaktans}

Når problemet med skærmtid er så stort og berører så mange, er det oplagt at spørge, hvorfor der ikke er flere, der handler og tager stilling. Svaret involverer psykologi, ideologi og individuelle interesser. Psykologi, fordi vi som mennesker sjældent er opmærksomme på, at vi er uopmærksomme, og fordi vi som mennesker per refleks yder modstand, når vi oplever, at andre vil begrænse vores frihed (reaktans). Ideologi, fordi der ifølge Christensen på mange uddannelsessteder hersker en teknologioptimisme, hvorved man med kritik af teknologien risikerer at udløse en religionskrig, hvor man stemples som teknologifjendsk. Individuelle interesser, fordi det for den enkelte underviser er forbundet med hurtig og sikker konflikt og langsigtet og usikker gevinst at tage kampen op. Intet er dermed mere oplagt end ikke at gøre noget.

Sidstnævnte - ikke at gøre noget - er dog ikke en pædagogisk acceptabel mulighed, for Christensens hovedpointe er følgende: Den digitale adfærd påvirker de aktiviteter og den læring, der foregår på uddannelsesstedet, og derfor er skærmtid en pædagogisk udfordring, der skal tages stilling til. Bogens sidste kapitel er således en diskussion af, hvad der kan gøres, og under hvilke omstændigheder vi kan gøre os håb om at begrænse eller endda helt forbyde skærmtid. 


\section{En diskussion på baggrund af fakta}

Christensens bog udmærker sig efter min vurdering på en række punkter, hvoraf jeg vil fremhæve tre.

For det første er det et helt afgørende bidrag, at Christensen på et teoretisk og empirisk grundlag beskriver, hvorfor og hvordan skærmtid påvirker undervisning i det fysiske rum. Debatten om Facebook i undervisningen har raset lige siden de første bærbare fandt vej til auditorierne i starten af årtusindskiftet, men karakteristisk for denne debat har været, at den har været baseret på holdninger, og at det hurtigt er blevet en skyttegravskrig mellem undervisere, der beskylder studerende for at være dovne, og studerende, der beskylder underviserne for at være kedelige. Det er derfor mit håb, at vi med Christensens bog kan gå ind i en ny fase, hvor vi kan diskutere problemerne på baggrund af viden og en fælles forståelse af, hvorfor det er så svært at lade mobilen ligge i tasken - uanset om vi som studerende deltager i undervisning, eller om vi som undervisere deltager i et møde.

Et andet væsentligt bidrag er, at Christensen formår at formulere, hvad der er det unikke og særlige ved det fysiske møde mellem undervisere og studerende. Selv i en tid med store fremskridt inden for digital undervisning har de fleste undervisere nok stadig en fornemmelse af, at mødet med de studerende, ansigt til ansigt, er vigtigt og værdifuldt. De færreste vil dog nok kunne begrunde hvorfor. Og det er netop begrundelser der skal til, hvis man vil gøre sig håb om at begrænse skærmtid.

I forlængelse heraf er det, for det tredje, et stort bidrag, at Christensen med brug af teori og empiri formår at forklare, at undervisning i sin essens er et fælles anliggende. Et samarbejde. En samtale mellem flere parter. Dermed punkterer han effektivt den myte, at man kan deltage i undervisning og samtidig være på nettet med den begrundelse, at "det går jo ikke ud over andre end mig selv". Jo, det gør det! For som Christensen dokumenterer, er det umuligt at være til stede sammen uden at påvirke hinanden. Det er jo det, der netop er pointen ved at mødes. Ingen studerende er isolerede øer, og hvis det store potentiale i det fysiske møde skal forløses, så kræver det, at alle (eller i hvert fald langt de fleste) er fysisk til stede og mentalt nærværende.

\section{Et fælles ansvar}

Man kan diskutere, om de fortrinsvis amerikanske økonomiske, sociologiske og psykologiske teorier, som Christensen referer til, nødvendigvis og i alle henseender er gyldige i konteksten af en dansk videregående uddannelse. Man kan også diskutere, om Christensen, trods ihærdige forsøg, undgår at falde i den fælde at tegne et lettere stereotypt billede af de studerende.

Dette ændrer dog ikke på, at bogen Kig op! er anbefalelsesværdig til et meget bredt publikum, og at Christensens hovedpointe er svær at afvise:

Fordi skcermtid er et faelles anliggende, mener jeg [...] at det er uansvarligt, hvis ikke uddannelsessteder, fagansvarlige, undervisere og studerende sørger for at diskutere rammerne for brugen af skarme. Et frugtbart undervisningsmiljø kraever nemlig, at vi i perioder også er sammen uden et blåt skœr. (s. 49)

Den anbefaling er hermed givet videre. 